UDK 81’255.4:821.111(73)-311.6Wallace L. $=03=163.6$

\title{
BEN-HUR IN SLOVENIAN: TRANSLATIONS OF AN AMERICAN NOVEL ABOUT MULTICULTURAL ISSUES
}

\author{
Darja Mazi Leskovar
}

\begin{abstract}
The $19^{\text {th }}$ century American bestseller Lew Wallace's Ben-Hur: A Tale of the Christ (1880) ranks among those novels that have been translated several times into Slovenian. The translations appear to be of particular interest for research from the multicultural perspective since they do testify not only to the bridging of the gap between the Slovenian and American cultures from 1899 on but also to shifts in the familiarity of the targeted Slovenian audience with the cultures of the Near East and with the Judeo-Christian tradition. By highlighting the domestication and foreignization translation procedures, applied to make the adaptations of the novel accessible to the target audience, the study focuses on the changing translation zones and overlapping spaces created between the Slovenian culture and the cultures described in the novel. The article furthermore stresses the differences between the translations as far as the targeted readers are concerned, since the epic ranks among double audience books.
\end{abstract}

Key words: Lew Wallace, translations of the American novel Ben Hur into Slovenian, multicultural issues, Judeo-Christian tradition, adaptations of the bestseller, changing translation zones, domestication and foreignization translation procedures, double audience.

\section{INTRODUCTION}

The novel Ben-Hur: A Tale of the Christ was first published in Slovenian translation in 1899, 19 years after its publication in the USA. Despite this time-lapse, the novel was the third work of American fiction to be translated into Slovenian and to address adult and younger readers alike. It followed the publications of Benjamin Franklin's Poor Richard's Almanach, published in Slovenian as Prava pot k dobrimu stanu, ali ena beseda ob pravim času in 1812 and Harriet Beecher - Stowe's Uncle Tom's Cabin. According to literary history, Wallace's novel was an instant success and its popularity shortly established in the whole English speaking cultural area: in two decades thirtysix English-language editions were published. At the threshold of the twentieth century Ben-Hur ${ }^{1}$ was translated into twenty languages ${ }^{2}$. It has entered the USA literary reposi-

\footnotetext{
${ }^{1}$ The shortened form of the title will be used for practical reasons.

${ }^{2}$ Amy Lifson, in Humanities.
} 
tory since from its first publication it has never been out of print. Until the publication of Margaret Mitchell's novel Gone with the Wind (1936), it even outsold every book except The Bible. Ben-Hur occupied the top bestseller position again in the 1960s, after the release of the blockbuster film with the same title. This book made Lewis Lew Wallace $(1827$ - 1905) a celebrity, even though he made his reputation also as a politician, general and a governor. Today he is the only novelist honoured in the National Statuary Hall of the U.S.A. Capitol ${ }^{3}$ and he has been remembered for his historical novels and above all Ben-Hur: A Tale of the Christ.

This novel has an exceptional position in the culture of American media. It overcame the suspicion of fiction that still prevailed in the late nineteenth century. It also helped the American audience to become theatre friendlier. Film adaptations of the novel (1907, 1925, 1959 and 2003) did not diminish the popularity of the book. The 1959 movie has even an exceptional position in the history of the film since it won 11 Academy Awards, a feat equalled only by Titanic (1997) and The Lord of the Rings: The Return of the King (2003) (http://en.wikipedia.org/wiki/Ben-Hur_(novel).

\section{ON ADAPTATION, DOUBLE AUDIENCE PHENOMENON, DOMESTICATION AND FOREIGNIZATION}

The story about Ben-Hur was published five times in Slovenian: in 1899, 1908, 1931, 1974 and in 1997.

In this paper the term 'adaptation' will be used in relation to all Slovenian translations of Ben-Hur, since, according to contemporary translation theories, all translations are adaptations as they try to adapt the original to the target language and to the cultural context of targeted readers (Anderman and Rogers: 2003). In the case of translations of Ben-Hur, the source cultural context is characterized by two aspects: the American context of the author and his source audience and the cultural context of the story. The chronotope of the novel is the ancient Middle East, the historic background which witnessed the clashes of cultures, particularly the confrontations between Jewish culture, the Roman culture and Christianity. Even though issues of culture and ideology are central to most of the analysis of literature, they are particularly relevant to books dealing with encounters between cultures and those which present the environments where different traditions meet. Such books tend to be especially popular with readers when authors make them feel personally involved with the topic concerned. Such involvement can help readers establish a personal bond with the fictional matter dealing with politics and religion and the setting of the historical cradle of both Judaism and Christianity and the atmosphere and tone which reveal the author's own personal engagement with the issues elaborated in the book. Despite the generally accepted view that the combination of facts and fiction has a "considerable past in the history of Anglo-American literature" (Flis 2010: 2), each literary work subsumes the possibility of uncovering new aspects of the interplay between the facts known from cultural history and the fictional elements. In

\footnotetext{
${ }^{3}$ http://www.neh.gov/news/humanities/2009-11/BenHur.html
} 
the case of translations, the very different cultural contexts of the source and the target readers may add a new complexity to the understanding of the interplay between facts and fiction. Therefore the specific case of the translations of Ben-Hur into Slovenian appears to be especially interesting.

In several world classics, the borders between adult and children's literature have been blurred. Particularly prose texts are relatively frequently ranked among double audience literature which includes two types of books: those written with teenage or even younger readers in mind and which are read by adults as well, and literary works published for adults but discovered by younger readers. Ben-Hur can also be considered a double audience book, originally written for adults but attracting also younger readers. Literary criticism classifies such books as 'crossover literature' (Falconer: 557-573). When such books are translated, the translation strategies of domestication and foreignization are particularly important. Foreignization strategy, the effort to keep so many culturally specific elements of the original as possible, is related to the philosophic issues discussed by Russian philosopher and linguist Mikhail Bakhtin (Baker: 1998). The idea of foreignization finds its counterpart in domestication, the opposite concept, the aim of which is to adapt the text coming from another tradition to the cultural context of the target readers. The American translation scholar Lawrence Venuti considers foreignization and domestication as key translation strategies. For him domestication is the ideological reconstruction "of the foreign text in accordance with values, beliefs and representations that pre-exist in the target language" (Venuti, 1993: 209); as Saglia claims, domestication can occur when there is the possibility to create "overlapping spaces" that enable translation and rewriting" (Saglia, 2002: 96).

Even though the frequency of intercultural contacts normally increases the number of overlapping spaces, their creation depends also on other factors, for example on the prevalent ideology of the target culture and its compatibility with the ideas inspiring the original. In cases of reduced compatibility, particular authors or books can "fall into disgrace". Ben Hur is one of such books. It was issued in various epochs of Slovenian socio-political history, from the Austrian-Hungarian Empire to the independent Republic of Slovenia. The research will thus also highlight the correlation between socio-political reality and the changing translation zones as revealed by the five translations. The study of foreignization and domestication strategies will focus on proper names, names of persons and geographical names since these may be considered as relevant indicators of intercultural contacts producing overlapping semantic spaces.

\section{THE FIRST TRANSLATIONS}

The 1899 translation of Ben-Hur and the 1908 translation were both published in the A-H- Empire. They were based on the 1888 authorized edition in two volumes that was published in Leipzig by Bernhard Tauchnitz. ${ }^{4}$ Both translations can thus testify to a similar cultural and socio-political context, characterised, first of all by the importance of Christian religion in public and private life and also by the vitality and importance

\footnotetext{
${ }^{4}$ The book was published in the Collection of British authors (indented by the author of this article)
} 
of the bordering regions of Slovenian national territory for the cultural life of the entire nation. Gorica, the cultural centre of the central western part, was one of the places where printing industry was developed and the first two translations of Ben-Hur were published there. The second translation is based on the first one and there can be found only a few minor linguistic emendations performed by Ivo Šorli. The only real novelty, introduced by the second translator is that he changed Wallace's name Lewis into Ludvig which is the German form of the name. Consequently the analysis of the first translation is essential for the study of the translation as a mirror of the translation zones connecting the Slovenian socio-cultural context at the threshold of the $20^{\text {th }}$ century with the context of this American epic.

\section{THE 1899 TRANSLATION}

The novel was first translated by Peter Miklave who entitled the book Ben-Hur: roman iz časov Kristusovih/A novel from the time of Christ which is an adaption of the original title. The domestication procedure is thus obvious already on the front page: the replacement of the term 'tale' with 'novel' shows that the latter literary term was expected to attract a much more demanding public than the term 'tale'. Additionally, the author's first name, Lewis was changed into Ludvik, a name familiar to Slovenians. On the cover page there is also the information "Translated into Slovenian by Podravski" so that the work is immediately indicated to be a translation, which at the end of $19^{\text {th }}$ century was not always the case.

The Slovenian translation starts with the text itself; there is no preface or introduction to the novel to explain the cultural background of the novel. It can be thus presumed that the average targeted reader was expected to be sufficiently informed about the classical and Judeo-Christian traditions to understand the story. On the other hand, the translator explains a few terms that are considered today as part of the basic (international) vocabulary mainly derived from the classical languages. For example, on page 4 the term 'horizont' (Eng. horizon) is followed by the Slovenian synonym 'obzorje' in the brackets. On page 6, the term 'tunika' (Eng. tunic) is explained with a footnote, occurring on the same page. It tells the reader that this is a piece of clothing worn in ancient Rome. Domestication with explanation in the text is more frequent. It normally clarifies the terms belonging to other cultural zones, particularly the Arab world. The term 'kufiyeh' which the author explains for his American readers in brackets as "the kerchief of the head is at this day called by the children of the desert" (p. 3), is presented in the translation as a "scarf the inhabitants of the desert wear on the head," again in brackets. However, since the translation is an adaptation also as far as the length of the novel is concerned, some extensive explanation is shortened. The start of Chapter II is a good example of the applied adaptation and domestication strategy.

It reads in the original (p.6):

He wore the kamis, ${ }^{5}$ a white cotton shirt, tight-sleeved, open in front, extending to the ankles and embroidered down the collar and breast, over

${ }^{5}$ Indented in the original. 
which was thrown a brown woollen cloak, now, as in all probability it was then, called the $a b a$, an outer garment with long skirt and short sleeves, lined inside with stuff of mixed cotton and silk, edged all round with a margin of clouded yellow. His feet were protected by sandals, attached by thongs of soft leather. A sash held the kamis to his waist.

In the Slovenian translation the same passage reads (5):

Popotnik je imel na sebi "kamis" - belo srajco z ozkimi rokavi, odprto na prsih široko od spodaj, vezano na vratu in prsih; zvrhu je nosily črn volnen plašč, imenovan "abba", s kratkimi rokavi, podvlečen s svilo in obrobljen z zlatom. Na nogah je imel opanke.

It can be noticed that in the original text the explanation of the term 'kamis' is part of the sentence where the term appears for the first time; however, in the translation the shorter explanation is given after the dash, following the term itself. This difference in punctuation indicates that the translator has tried to follow the original closely, even though he has also used the freedom to shape sentences according to the needs of the Slovenian language. Despite the shortening of the text, the translator keeps all the parts in which Wallace tried to bring the foreign world with its realia nearer to American readers, since they were essential also for the Slovenian readers. In addition, when he considers that the foreignization is too pronounced for an average targeted reader of the translation, he introduces additional explanative material, as has been already shown with the examples 'horizon' and 'tunic.'

The translator translates only the tale. He omits the introductory thought of Count Gabalis, claiming that in every instance natural causes should be sought, and only in cases when this is not possible should divine explanations be looked for. Nor are the quotations from literature that introduce each chapter in the original translated. As the original, also the Slovenian text is divided into eight books, each of which contains several chapters. The chapters of the story are shortened and adapted, according to the translator's interpretation of the importance of individual chapters. Thus the Second chapter of the First Book, relates the second and the third chapter of the original, in which the three Magi, Balthasar from Egypt, Gaspar, from Greece and Melchior from India, meet and in which, by telling each other stories, they realize they have been brought together by their determination to find the place where the saviour of the mankind will be born. Another instance of change is where the fifth, sixth and seventh chapters of the Fourth Book are retold together in the fifth chapter of the Slovenian adaptation. Only a few passages are left out altogether, for instance, the song of Ben Hur's sister Tirzah in the sixth chapter of the Second Book. Also the Egyptian elegy from the seventeenth chapter of the Fourth Book cannot be found in the Slovenian translation. On the other hand, examples can be found where the translator expands the original text. In the seventh chapter of the Second Book, the sentence "The Lord help him" (158) is rendered with "Naj mu pomaga Bog Izraelov, Bog Abrahamov in Jakobov/May he be helped by the God of Israel, the God of Abraham and Jacob" (40). The most obvious extension, however, is the introduction of titles given to most of the chapters. For instance, 'BenHur in Messala'/Ben-Hur and Messala, or 'Znovič Jeruzalem/Jeruzalem again. 
Despite all abbreviations, the Slovenian translation conveys the essence of the story in which the narrative of Judah Ben-Hur intertwines with the stages in the life of Jesus Christ. Ben-Hur, a Jewish prince is accused of trying to murder the Roman procurator. Without trial he is sent to work as a slave on a Roman galley, his mother and sister are imprisoned and the family property is confiscated. However, Ben-Hur manages to regain his freedom and he returns home to find his family and to take revenge on Messala, the person who is responsible for their misfortunes. After a few encounters with Jesus, Ben-Hur starts reflecting about the Saviour in other terms than those of traditional Judaism, even though he follows those who challenge Romans and talk about the great Jewish kingdom. Particularly after Jesus miraculously heals his mother and sister from leprosity, he is more and more inspired by the great Rabby and eventually becomes his follower. As a Christian, he abandons the idea of vengeance and is willing to help others to live according to their faith.

Foreignization and domestication of the text can be revealed through translation of proper personal and geographical names. Geographical names known from the classical tradition and the Biblical world were translated according to the already established forms, generally accepted in the target cultural context which was the context of Christian society. So, Judea became Judeja, Nazareth became Nazaret, Bethlehem was turned into Betlehem. Galilee was rendered as Galileja, Thessaly got the Slovenized form Tesalija and Jericho was changed into Jeriha. Some of the changes in names seem to be connected with the rules guiding Slovenian pronunciation, as it is the case of Mecca which was changed into Mekka: the letter ' $\mathrm{k}$ ' indicates in Slovenian the sound $/ \mathrm{k} /$, thus the same pronunciation as it is required for the letter ' $c$ ' in the English name of the holy Muslim town.

Also with personal names the author followed various domestication and foreignization strategies. A few names remained unchanged, as Messala, the name of Judah's childhood friend who turned into a most malicious enemy, Simonides, the name of Judah's advisor and father-in-law. Other names were changed following the principles presented when discussing changes in geographical names. Names related to Christian tradition were given Slovenian domesticated equivalents. So Joseph and Mary became Jožef and Marija. Names which are also known in Slovenian, were given their Slovenian form, i.e. Esther became Estera. Domestication of some names occurred on the spelling level: the name of Judah's sister Tirzah was written without the final ' $h$ '. A similar change occurred in the case of Balthasar which was therefore domesticated into Baltazar.

The balance between domestication and foreignization strategies in the field of geographical and personal names thus contributes to the accessibility of the text for the targeted readers at the start of the $20^{\text {th }}$ century.

\section{THE 1931 TRANSLATION}

The 1931 translation was published in the time of the Kingdom of Yugoslavia in Ljubljana, the centre of the part of Slovenian territory which was part of Yugoslavia. This was the period in which classical education was appreciated and in which the basic knowledge related to Judeo-Christian tradition was expected to be a constituent part of general education. 
The translator, Griša Koritnik, wrote the author's name in its original form: Lewis Wallace. Ben-Hur was presented as 'Povest iz Kristusovih časov'/A Tale from the time of Christ. He did not translate only the three introductory texts, but also the three introductory texts which should reveal the author's attitude to his work: the Cont Gabalis'a advice about following the example of the wise, Jean Paul F. Fichter's ideas about the positive impact of the repetition of the known old stories which reveal pleasant thoughts and also Milton's hymn about Christ's birth. This translation brings the entire text of the original since it includes also all quotations from literature with which Walles introduces the individual books constituting the novel of Ben-Hur. As the quotations are taken from British and American literature, this can be viewed as a proof that the degree of familiarity of the targeted Slovenian audience with the English speaking cultural context was sufficient to present the readers with the quotations from renowned literary masterpieces. The Second book was thus introduced with a translation of the citation from Lord Byron's Childe Harold, and the Third with a quote from Shakespeare's Antony and Cleopatra (Act IV., Sc.XIII.). Also the Slovenian translation introduces Book Seven with the quote of Thomas Bailey Aldrich, the American poet and novelist and Book Four with the quotation from Schiller's Don Carlos (Act IV., Sc. XV). Shiller's quote certainly created the impression about the universality of this theme among non-English speaking cultures.

The layout of the novel is respected: the text is divided into two volumes each of which is further divided into Books consisting of several chapters. The degree of domestication of the text is much more restricted than in the previous translations. Several terms explained in the footnotes are related to the Jewish religious tradition, as for example the terms 'hasan' and 'tora' (p. 55). Others are a sign of the translator's desire to make the content of the narrative understandable to his contemporaries: there is, for instance the clarification of the value of Roman silver coin in dinars, the monetary unit used by the readers in the Kingdom of Yugoslavia (p. 39). The principle of domestication of names, explained in the section discussing the 1899 translation, is also respected in this translation. The domesticated names that were introduced into a Slovenian cultural context with the 1899 translation, keep their form in this translation. Still, foreignization is diminished by the elimination of the double consonant in the name Messala. The spelling 'Mesala' is slovenized, though the name itself remains foreign as far as targeted readers are concerned.

\section{THE 1974 TRANSLATION}

The 1931 translation was used as the basic text for the 1974 adaptation which also retains the same title: Ben-Hur Povest is Kristusovih časov/A Tale from the time of Christ. The text of Griša Koritnik was adapted by Jože Podbrezar and published by Mohorjeva Družba in Celje. This adaptation was published in the midst of a period characterised by communist and socialist ideology and its antireligious propaganda. Its special feature is the inclusion of concluding remarks entitled $O$ knjigi in pisatelju/On the book and the author. 
The accompanying text explains that this adaptation was published because there was a continuing audience demand for the novel which is such a success with American audiences: the only comparable instances are those of the attention given to BeecherStowe's Uncle Tom's Cabin and the works of Walter Scott and Charles Dickens. The successful dramatisations of the bestseller are also listed. What is particularly important from the perspective of the current study is the information that Ben-Hur influenced Sienkiewicz's Quo vadis (1894-1896), a novel popular with generations of Slovenian readers. Moreover, the commentary gives a short but effective analysis of the features of the critics' opinion of the style, including the drawbacks, such as sentimentality and pomposity. It underlines the black-white characterisation which goes in line with the intention of the book to present the struggle between good and evil, a fight that is finally won by the good. The reasons for such an ideology in the narrative are to be found in the author's life. Wallace's aim was to put a stop at Anti-Semitism and to pinpoint the true Christian values. However, this commentary presents Lewis Wallace above all as a fighter who protected law and order as well as the rights of the oppressed, something which was an important piece of information in the 1970s, when the Yugoslav governing elite featured the communist-socialist regime as the supporter of the oppressed all around the world. Consequently the idea of the envisaged victory of the oppressed is also stressed. Since the book was published by the only publishing house which printed Christian-oriented texts, it can be presumed that this socio-cultural commentary was not only necessary but also welcomed by the public authorities.

The text had to be newly adapted, as language changes and the forty year lapse demands some adaptation towards the contemporary ways of expression as well as to the characteristics and expectations of the new reading audiences. From the point of view of layout this translation distances itself from the previous one since, first, the explanatory notes appear only at the end of the narrative, and second, because the chapters are indicated only with numbers, expressed in words. These changes make the text more mature-reader oriented. The new translation thus meets the changes that had occurred in the taste and interests of the targeted adult-reader. Some passages that would presumably not be particularly interesting for the presumed 1970 audience have been therefore left out. In particular the detailed descriptions, for example of buildings and palaces, were shortened considerably. Also a few longer discussions which slow down the action of the narrative have been either deleted or shortened. As a result, readers who presumably had less classical and theological background than the audience addressed by the previous translations would find more accessible a literary work which in its original form presents a series of demanding theological, historical and philosophical issues. This adaptation thus responded to the needs of the new reading public and it has since then been keeping alive the interest of Slovenian readers.

\section{THE 1997 TRANSLATION}

The 1997 translation of Ben-Hur, a translation of the adaptation of Wallace's novel written by the American writer Anne de Graaf, was published in the new socio-political context, created by the founding of the Republic of Slovenia. The book, which is a 
picture book, was published by Mohorjeva Družba and translated by Marko Dobravec. The English adaptation has the same title as Wallace's original: Ben-Hur A Tale of the Christ. The Slovene title is Ben-Hur Zgodba iz Kristusovih časov. On the cover itself it is also stated that the story is retold by Anne de Graaf for today's children. The same information is given on the Slovenian cover, thus classifying the book as reading for children

The book starts with an introductory page provided by the Slovenian editor. The introductory commentary gives the basic information on the novel and its author. It stresses that the book was an immediate success and that Lewis Wallace held various important positions in American public and political life. As an advocate of those who were denied human rights, he is said to have mirrored his own turbulent times in the story of a young man who had to experience humiliation but who was strong enough to preserve his pride and dignity and finally to admit that Jesus is the Redeemer. The introduction also brings the chronology of Slovenian translations. It is stressed that the first adaptation was published as early as 1899 . The passage concludes with the introduction of Anne de Graaf who is presented as a children's literature author whose aim was to tell the classical story in simple contemporary language so that it could successfully address modern children.

The text of the narrative consists of 28 adapted chapters, each of which has a title. The chapters of the story are shortened, according to the translator's interpretation of the importance of individual passages of the text for the child reader. Thus, for example, the second chapter, entitled 'Kralj vseh kraljev/King of kings', talks about the encounters of the Three Magi with Herod and Jesus, the baby-boy. The fifth chapter, Ob vodnjaku/At the fountain, describes the first encounter between Jesus and Ben-Hur, both teenagers. The seventh chapter, 'Bitka na morju/Sea battle' tells why the famous Roman, Quintus Arrius, adopted the main hero as a young man. The final chapter, 'Božji načrt/God's plan', presents Ben-Hur hurrying to be near Jesus after he was arrested, as well as the crucifixion and the changes in the life of those who believed that Jesus was the Lord. The layout of the story is also adapted to the child reader: the text is rendered in short paragraphs and most of the narrative is advanced through dialogue. Compared to names used in previous Slovenian translation, domestication strategy is even more strictly applied: the name of Simonides is domesticated into Simonid and Balthasar is slovenized into Boltežar. The latter name is rather familiar to children since it is connected with Slovenian folk traditions in which children play an important role.

This picture-book is lavishly illustrated with the original colour illustrations of Willem Zijlstra. The artist presents selected scenes described in the text and therefore contributes essentially to the understanding of the storyline and the message of the story. Particularly valuable are the illustrations showing cultural aspects related to Roman and Jewish traditions, as for instance the image of the galley and of Jerusalem, both of which might otherwise have been difficult for targeted readers to imagine. The picture-book format opens up a new perspective on narrative within the Slovenian cultural context, while at the same time remains of interest to both young readers and the larger reading public: research proves that picture-books have given rise to an expanded reading audience (Nikolajeva and Scott: 2001). Other research shows that the so called 'classics' tend frequently to change their position and audience (Beckett: 2002). 


\section{CONCLUSION}

This survey of translations of Ben-Hur into Slovenian reveals that of five translations, four are uncovering time-specific attitudes related to the culture of the USA and issues connected with multiculturalism. Since they were issued in four different sociopolitical contexts, they testify not only to their audiences' increasing familiarity with the English-speaking cultures but also to a shift in familiarity with the Middle East and the Judeo-Christian tradition. The latter has been strongly influenced by the cultural and ideological policies of each of the particular government systems towards religion as well as by the secularisation tendencies typical of the Central and West European contexts. The application of domestication and foreignization translation strategies with reference to names of persons and places furthermore proves that the domestication principle has increasingly gained ground. Even though literary theory holds that Ben$H u r$ is a cross-over fiction, audiences of the first four Slovenian translations have not been specified. It can be presumed that the narrative was read by readers from teen-age or young adulthood onwards. Conversely, the 1997 translation aims at children. At the end of the twentieth century, the novel has thus gained a new position in the Slovenian cultural history.

University of Maribor, Slovenia

\section{WORKS CITED}

Anderman, Gunilla and Margaret Rogers. Translation Today, Trends and Perspectives. Clevedon, Buffalo, Toronto, Sydney: Multilingual Matters Ltd., 2003.

Apter, Emily. The Translation Zone. Princeton: Princeton UP, 2006.

Baker, Mona (ed.). Routledge Encyclopaedia of Translation Studies. London and New York: Routledge, 1998.

Beckett, Sandra. Transcending Boundaries. Writing for a Dual Audience of Children and Adults. New York: Garland Publishing, 2002.

Falconer, Rachel. "Crossover Literature". International Companion Encyclopedia of Children's Literature. Ed. Peter Hunt. New York: Routledge, 2004. 557-573.

Flis, Eleonora. Factual Fictions. Newcastle upon Tyne: Cambridge Scholars Publishing, 2010.

Hunt, Peter (ed.). International Companion Encyclopaedia of Children's Literature New York: Routledge, 2004.

Kenny, Dorothy. "Equivalence”, Routledge Encyclopaedia of Translation Studies. Ed. Mona Baker. London and New York: Routledge, 1998. 77-80.

Nikolajeva, Maria. How Picturebook Works. New York and London: Garland Publishing. 2001.

Venuti, Lawrence "Translation as Cultural Politics: Regimes of Domestication in English." Textual Practice, 7, 1993. 208-23.

Saglia, Diego. "Translation and Cultural Appropriation: Dante, Paolo and Francesca in British Romanticism”, Quaderns. Revista de traduccion 7, 2002. Wallace, Lewis. Ben-Hur A Tale of the Christ. Leipzig: Tauchnitz, 1888.

Wallace, Lewis. Ben-Hur A Tale of the Christ. Ware: Wordsworth Classics, 1996.

Wallace, Lewis. Ben-Hur Povest iz Kristusovih časov. Gorica: Goriška tiskarna, 1899.

Wallace, Lewis. Ben-Hur Povest iz Kristusovih časov. Gorica: Goriška tiskarna, 1908.

Wallace, Lewis. Ben-Hur Povest iz Kristusovih časov. Ljubljana: Jugoslovanska knjigarna, 1931.

Wallace, Lewis. Ben-Hur Povest iz Kristusovih časov. Celje: Mohorjeva družba, 1974. 
Wallace, Lewis. Ben-Hur Zgodba iz Kristusovih časov. (Priredila Anne de Graaf). Celje: Mohorjeva družba, 1997.

http://en.wikipedia.org/wiki/Ben-Hur_(novel), Ben Hur, July 1, 2011. 